\title{
A Literature Review of Representation Models of E-Business Models from the Perspective of Value Creation
}

\author{
Zhicheng Guo \\ Management School, Jinan University, Guangzhou, China \\ Email: zcguofuture@163.com
}

Received 11 January 2016; accepted 21 February 2016; published 24 February 2016

Copyright (C) 2016 by author and Scientific Research Publishing Inc.

This work is licensed under the Creative Commons Attribution International License (CC BY). http://creativecommons.org/licenses/by/4.0/

c) (i) Open Access

\begin{abstract}
Business model is abstract rational cognition about how corporation created, delivered and obtained value and is the enterprise's core competitive advantages from the perspective of value creation. This article found that research perspective of representation models of e-commerce business model mostly concentrated on value creation perspective and there are two categories: EBMO and $\mathrm{e}^{3}$-value Model. We respectively discuss the two categories in order to make better understanding of the current development in e-commerce business model research.
\end{abstract}

\section{Keywords}

Value Creation, E-Commerce, E-Business Model, Representation Model

\section{Introduction}

Since 1990s, with the rapid development of the Internet, e-commerce has begun to emerge at that historic moment. The impact of e-commerce, which not only affects the business as well as people's work, but also affects people's behavior, has become an important part of the national economy growth [1]. Due to the rapid development of e-commerce, the concept of business model has been the focus of substantial attention from both academics and practitioners [2]. E-commerce business model is significantly different from the business model of traditional corporate, and has played an important role in the development and expansion. How did e-commerce company win other competitors in the fierce market competition? It not only depends on its own strength, but also depends on business model. Competition in modern corporations is the competition of business rather than the competition of products.

This paper includes four parts: 1) the introduction describes the writing background of this paper; 2) the con- 
cept of business model and e-business model allows readers to deepen the understanding of this topic; 3) Section 3 is the main part of this paper, and discusses in detail the research status, classification and the tendency of the e-business models research from the perspective of value creation; 4) the conclusion briefly reviews the previous parts of this study.

\section{Business Model and E-Business Model}

\subsection{Business Model Definitions}

The character of business model firstly appeared in 1957 in the paper text [3], business model has been prevalent with the rapid development and popularization of Internet as well as rapid development of e-commerce, and it has gradually formed an independent field of study with an explosion in the number of articles published. So far, however, despite the overall surge in the literature on business models, the concept of business model has not been consensus in academic; there are different explanations from different scholars due to their different research perspective. At a general level, the business model has been referred to as a statement, a description, are presentation, an architecture, a conceptual tool or model, a structural template, a method, a framework, a pattern, and a set [2].

A business model describes the logic of a "business system" for creating value, which lies behind the actual processes [4]. Another, a business model is a description of the value a company offers to one or several segments of customers and the architecture of the firm and its network of partners for creating, marketing and delivering this value and relationship capital, in order to generate profitable and sustainable revenue streams [5]. Amit \& Zott (2001) defined that the business model depicts the content, structure, and governance of transactions designed so as to create value through the exploitation of business opportunities [6]. Based on the fact that transactions connect activities, the authors further evolved this definition to conceptualize a firm's business model as a system of interdependent activities that transcends the focal firm and spans its boundaries [7]. Similarly, business models consist of four interlocking elements that taken together, create and deliver value. These are customer value proposition, profit formula, key resources, and key processes [8]. And Teece (2010) defined that a business model articulates the logic, the data and other evidence that support a value proposition for the customer, and a viable structure of revenues and costs for the enterprise delivering that value [9].

\subsection{E-Business Model Definitions}

The research stream that, to date, has devoted the greatest attention to business models concerns e-business. The term e-business means “doing business electronically” [2]. Shafer et al. (2005) reviewed 12 definitions in established publications during the period 1998-2000, finding that 8 were related to e-business [10]. Similarly, Zott and Amit's (2011) literature review confirmed this trend, in a total of 49 conceptual studies in which the business model is clearly defined, almost one fourth of the studies are related to e-business [2].

The term e-business model (e-commerce business model or electronic business model) was first defined by IBM in the 1990s as the transformation of key business processes through the use of internet technologies [11]. An electronic business model is an important baseline for the development of e-commerce system applications [12]. Rappa (2007) defines the e-business model in its most basic sense, as a method of doing business by which a company can sustain itself by generating revenue. He identifies how a firm makes money by specifying where it is positioned in the value chain [13]. Timmers (1999) defines an e-business model as an architecture for product, service and information flows, including a description of the various business actors and their roles; the potential benefits for the various actors; and the various sources and revenues [14]. Weill et al. (2001) describe eight so-called "atomic" e-business models, each of which describes a different way of conducting business electronically; e-business initiatives can be represented by pure atomic business models or by combining them [15].

\section{The Study of Representation Models of E-Business Models from the Perspective of Value Creation}

Research on e-business models can be organized around two complementary streams: The first aims to describe generic e-business models and provide typologies; the second focuses on the components of e-business models [2]. And many authors have attempted to represent e-commerce business models through a representation models (e.g., [12] [16]-[27]). Table 1 presents a summary of these efforts. 
Through analysis these literatures, we surprisingly found that about $80 \%$ of these research of e-commerce business models was based on the perspective of value creation (Table 2), and Yuan Lei (2007) have took a similar conclusion that business model is fundamentally logic of value creation [3]. The perspective of value creation in the research of e-commerce business model is a widespread and greatest influent field [27]. The perspective of value creation can help to understanding the dynamic and systematic of business models [7]. Similarly, Yuan Lei (2007) propose a framework, which could be called "3-4-8" constitutes system, for understand and dialysis business model [3]. Therefore, this framework can help to examining the components of these representation models [28].

Among the articles of the research perspective of value creation, there are $50 \%$ of those which were employed the model of EBMO, as well as some of other articles were employed the $\mathrm{e}^{3}$-value model. Table 3 presents a summary of these efforts.

Table 1. Components of representation models of e-business models.

\begin{tabular}{|c|c|c|}
\hline Author(s), Year & Components & Numbers \\
\hline Gordijn et al. (2001) [12] & $\begin{array}{l}\text { Actor, Value object, Value offering, Value activity, Value port, } \\
\text { Value interface, Value exchange }\end{array}$ & 7 \\
\hline $\begin{array}{l}\text { Dubosson-Torbay } \\
\text { et al. (2001) [19] }\end{array}$ & $\begin{array}{l}\text { Product innovation, Customer relationship, Infrastructure management, } \\
\text { Financial aspect }\end{array}$ & 4 \\
\hline Afuah et al. (2001) [20] & Scope, Price, Connected activities, Implementation, Capabilities, Sustainability & 5 \\
\hline Alt Zimmermann (2000) [21] & Mission, Structure, Processes, Revenues, Legal issues, Technology & 6 \\
\hline Wendy L. Currie (2004) [22] & Strategic positioning, Product/Services Portfolio, Value proposition, Value capture & 4 \\
\hline Linder \& Cantrell S (2001) [23] & $\begin{array}{l}\text { Pricing model, Revenue model, Commerce process model, Internet-enabled } \\
\text { commerce relationship, Organizational form, Value proposition }\end{array}$ & 6 \\
\hline Mahadevan (2000) [24] & Value stream, Revenue stream, Logistical stream & 3 \\
\hline Van Der Vost et al. (2002) [25] & Value proposition, Roles of participants, Processes, Functionalities, Applications & 5 \\
\hline Osterwalder (2005) [16] & Relationship, Value configuration, Capability, Cost structure & 4 \\
\hline $\begin{array}{l}\text { Bhavini Desai \& Wendy Currie } \\
\text { (2008) [26] }\end{array}$ & $\begin{array}{l}\text { Market positioning, Customer expectation, Value proposition, } \\
\text { Products and services, Revenue, Delivery model }\end{array}$ & 6 \\
\hline $\begin{array}{l}\text { Abdelkafi N \& Makhotin S } \\
\text { et al. (2013) [17] }\end{array}$ & Value proposition, Value creation, Value delivery, Value capture, Value communication & 5 \\
\hline
\end{tabular}

Table 2. The research perspective of representation models of e-commerce business models.

\begin{tabular}{cccc}
\hline $\begin{array}{c}\text { Research perspective } \\
\text { The perspective of value creation }\end{array}$ & Article numbers & Proportion & Representative model \\
\hline Other perspective & 48 & $80 \%$ & $\begin{array}{l}\text { E-business model ontology for modeling e-business } \\
\text { (EBMO, [16]) } \mathrm{e}^{3} \text {-value Model [12] }\end{array}$ \\
\hline
\end{tabular}

Table 3. The representation models of e-commerce business model from perspective of value creation.

\begin{tabular}{|c|c|c|}
\hline Author(s), Year & Components of Model & Numbers \\
\hline $\begin{array}{l}\text { Osterwalder et al. } \\
(2001,2005)[16]\end{array}$ & $\begin{array}{l}\text { Product (Value Proposition); Customer Interface (Target Customer, Distribution Channel, } \\
\text { Relationship); Infrastructure Management (Value Configuration, Core Competency, } \\
\text { Partner Network); Financial Aspects (Cost Structure, Revenue Model) }\end{array}$ & 21 \\
\hline Gordijn (2001) [12] & Actor, Value Object, Value Offering, Value Activity, Value Port, Value Interface, Value Exchange & 7 \\
\hline \multicolumn{2}{|c|}{ Other authors (the numbers that were cited are less than 2) } & 15 \\
\hline
\end{tabular}




\subsection{E-Business Model Ontology (EBMO)}

Osterwalder and Pigneur (2005) proposed a new e-Business Model Ontology. The e-business model ontology describes the logic of a "business system" for creating value in the Internet era and composed of four main pillars, which are product innovation, infrastructure management, customer relationship and financial aspects [16] (Figure 1). This model exhaustively describes components of e-business model from the perspective of value creation by using the networking modeling approach [3], as well as has been widely applied by many scholars (e.g., [17]-[19] [29]-[33]) and managers in both academics and practices.

Susan Lambert (2008) proposed a conceptual framework for business model research that provides a basis for theory development and debate. This business model conceptual framework will guide future research and that it will be reviewed and refined, just as the financial reporting conceptual framework has been reviewed and refined over decades [29]. Delvin Grant (2013) use EBMO to analyze e-business models in online real estate. The author investigate the similarities and differences among e-business models and how e-business model differentiation affects company success to discovering which business model components are important as well as which model are more successful. They discover that differences include the use of revenue streams for generating revenue, the extent of partnerships and the role play in a company's success [18]. Based on EBMO, Abdelkafi et al. (2013) introduces a new framework, in which a business model denotes a value-focused concept with five dimensions: value proposition, value communication, value creation, value delivery and value capture in the field of electric mobility. The combination of patterns from different dimensions can lead to the systematic generation of business model innovations and evaluates the extent to which business model patterns can be useful for the field of electronic mobility and how they can be adapted to fit into the new context [17]. Konstantinos N. $\mathrm{G}$ et al. (2011) emphasizes the need for ITS to take advantage of the developments in Information and Communication Technologies (ICTs) and the internet, and proposes some e-business model framework for ITS, as well as addresses sustainability issues and aspects of the network economy for ITS companies [30]. Dubosson-Torbay et al. (2001) proposed a theoretical e-business model framework for doing business in the Internet era. This framework's objective is to define critical success factors, based on a field study in order to find out and compare the performance indicators used by e-business firms which are competing with similar business models [19]. Xiaobo Wu et al. (2010) explore the new latecomer advantage implied in the phenomena of overshooting and non-consuming. Based on inductive theory building with a comparative case study, the authors find that latecomer firms, though disadvantaged in technological capabilities and market resources, can successfully introduce disruptive technologies from advanced economies into emerging economies through secondary business-model innovations [31]. Basing on EBMO, Novaes Zilber et al. (2012) described the business model of small companies that have adopted e-business in an emerging Latin American country and found that the owners/shareholders play a central role in making decisions about the adoption of e-business as well as the main value delivered from using the internet was improved brand and/or product awareness [32]. Using EBMO, Kiani et al. (2009) proposed causal loop diagram (CLD) and use it as a useful tool to capture the structure of e-business systems in order to achieve a better understanding of an e-business model. And, the proposed CLD provides managers with significant insight into the e-business models [33].

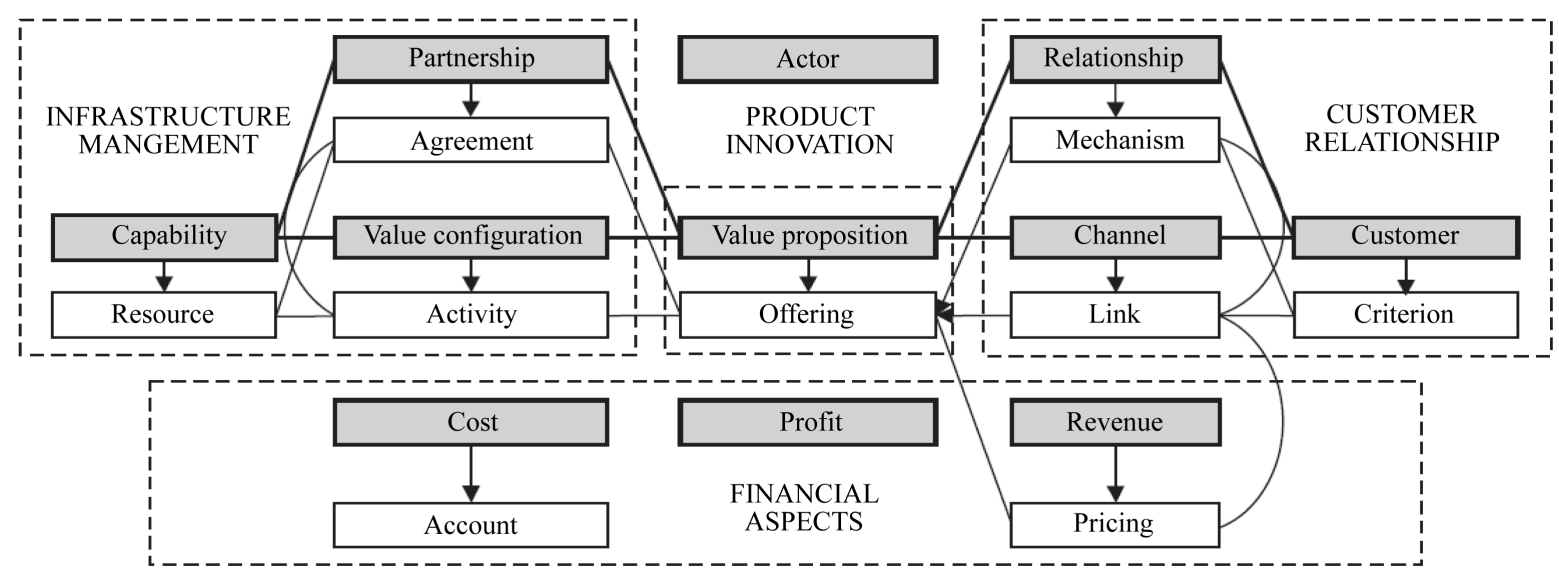

Figure 1. E-business model ontology (EBMO). 


\subsection{E3-Value E-Business Model}

Gordijn and Akkermans et al (2001) presented a ontology of e-business model which called $\mathrm{e}^{3}$-value to developing e-business model ontology which centers around the core concept of value, and expresses how value is created, interpreted and exchanged within a multi-party stakeholder network [12]. This ontology which composes the components of actor, value object, value offering, value activity, value port, value interface, value exchange has been widely applied by many scholars (e.g., [34]-[38]) by abstracting a simplified model of value creation.

$E^{3}$-value ontology focus on the notion of value and the way objects of value are created, exchanged and consumed in a stakeholder network [12]. C. Huemer et al (2008) focus on inter-organizational systems to describing e-business model for corporate network of actor and present a discussion of different approaches to present the $\mathrm{e}^{3}$-value concepts by means of UML. This approach can align specifying inter-organizational business processes for future work [34]. Glova J et al. (2014) apply $\mathrm{e}^{3}$-value to model value creation and value exchange within an e-business network of multiple business actors. And author use this approach to reduced to its core elements which includes value proposition, distribution channels, the customer of the company, and to explaining how a multi-actor network creates, distributes and consumes value by production of a good or providing a service [35]. OuYangfeng (2007) developed structure analysis based on $\mathrm{e}^{3}$-value ontology method, and study the e-business model of data service provider. This study revealed the internal dynamics mechanism of e-business models by constructing a value model to modeling the process how value created, added and exchanged between the participants in models [36]. And then, based on $\mathrm{e}^{3}$-value ontology method, OuYangfeng et al. (2008) constructed the value model for electronic books business model and carried out the profitability for all the actors involved and viability analysis of the business model through simulation [37]. Using $\mathrm{e}^{3}$-valuee-business model, Weiwei $\mathrm{Li}$ and Yue Dai (2011) designs one prototypical example of an online database provider company and discusses various business model value under different scenarios [38]. The $\mathrm{e}^{3}$-value ontology which analysis the corporate business models can link the corporates and consumers through the value chain and dialysis components in system of e-business models by modeling and simulating the models, as well as estimate the profitability and rationality of value model of e-business models.

\section{Conclusion}

Due to the rapid development of e-commerce, the concept of business model has been the focus of substantial attention from both academics and practitioners [2]. Business model is abstract rational cognition about how corporation created, delivered and obtained value and is the enterprise's core competitive advantages. Although, the business model is often studied without an explicit definition of the concept, our review found that research perspective of representation models of e-commerce business model mostly concentrated on value creation perspective (approximately $80 \%$ of all articles) and there are two categories: EBMO (approximately $50 \%$ of the articles from the perspective of value creation) and $\mathrm{e}^{3}$-value model (15\% of those articles). The e-business models exhaustively describe components of e-business model from the perspective of value creation by using the networking modeling approach, and have been widely applied by many scholars. The $\mathrm{e}^{3}$-value ontology which analyzes the corporate business models can link the corporations and consumers through the value chain and dialysis components in system of e-business models by modeling and simulating the models, and estimate the profitability and rationality of value model of e-business models.

\section{References}

[1] Turban, E., King, D., Lee, J., Liang, T.-P. and Turban, D. (2012) Electronic Commerce 2012: A Managerial and Social Networks Perspective. 7th Edition, Prentice Hall, Upper Saddle River.

[2] Zott, C., Amit, R. and Massa, L. (2011) The Business Model: Recent Developments and Future Research. Journal of Management, 1-25.

[3] Yuan, L. (2007) Reconstruction of Business Model Theory System. China Industrial Economy, 6, 70-79.

[4] Peterovic. O., Kittl, C., et al. (2001) Developing Business Models for E-Business. International Conference on Electronic Commerce 2001, Vienna, 31 October-4 November 2001.

[5] Osterwalder, A. (2004) The Business Model Ontology-A Proposition in a Design Science Approach. PhD Thesis, University of Lausanne, Switzerland. 
[6] Amit, R. and Zott, C. (2001) Value Creation in E-Business. Strategic Management Journal, 22, 493-520. http://dx.doi.org/10.1002/smj.187

[7] Zott, C. and Amit, R. (2010) Designing Your Future Business Model: An Activity System Perspective. Long Range Planning, 43, 216-226. http://dx.doi.org/10.1016/j.lrp.2009.07.004

[8] Johnson, M.W. and Christensen, C.M. (2008) Reinventing Your Business Model. Harvard Business Review, 11, 50-60.

[9] Teece, D.J. (2010) Business Models, Business Strategy and Innovation. Long Range Planning, 43, 172-194. http://dx.doi.org/10.1016/j.lrp.2009.07.003

[10] Shafer, S.M., et al. (2005) The Power of Business Model. Business Horizons, 48, 199-207. http://dx.doi.org/10.1016/j.bushor.2004.10.014

[11] Li, F. (2007) What Is E-Business? How the Internet Transforms Organizations. Blackwell Publishing, Oxford.

[12] Gordijn, J. and Akkermans, H. (2001) Ontology-Based Operators for E-Business Model De- and Re-Construction. Proceedings of the First International Conference on Knowledge Capture, Victoria, Canada, 21-23 October 2001, 60 67.

[13] Rappa, M. (2009) Business Models on the Web: Managing the Digital Enterprise. http://digitalenterprise.org/models/models.html

[14] Timmers, P. (1998) Business Models for Electronic Markets. Journal of Electronic Markets, 8, 3-8. http://dx.doi.org/10.1080/10196789800000016

[15] Weill, P. and Vitale, M.R. (2001) Place to Space: Migrating to E-Business Models. Harvard Business School Press, Boston.

[16] Osterwalder, A. and Pigneur, Y. (2005) Clarifying Business Model: Origins Present and Future of the Concept. Business, 15, 1-25.

[17] Abdelkafi, N., Makhotin, S., et al. (2013) Business Model Innovations for Electronic Mobility—What Can Be Learned from Existing Business Model Patterns? International Journal of Innovation Management, 17, 1-41.

[18] Grant, D. (2014) Analysis of E-Business Models in Real Estate. Electronic Commerce Research, 14, 25-50. http://dx.doi.org/10.1007/s10660-013-9126-z

[19] Dubosson-Torbay, M., Osterwalder, A. and Pigneur, Y. (2001) E-Business Model Design, Classification and Measurements. Thunderbird International Business Review, 44, 5-23.

[20] Afuah, A. (2005) Business Models: A Strategic Management Approach. McGraw-Hill, New York.

[21] Alt, R. and Zimmerman, H.D. (2001) Introduction to Special Section on Business Models. Electronic Markets, 11, 3-9.

[22] Currie, W.L. (2004) Value Creation from E-Business Models. Butterworth-Heinemann, Oxford, 370-408.

[23] Linder, J. and Cantrell, S. (2001) Changing Business Models: Surveying the Landscape. PhD Thesis, Accenture Institute for Strategic Change, Cambridge.

[24] Mahadevan, B. (2000) Business Models for Internet-Based E-Commerce: An Anatomy. California Management Review, 42, 55-69. http://dx.doi.org/10.2307/41166053

[25] Van Der Vorst, J.G.A.J., Van Dongen, S., Nouguier, S. and Hilhorst, R. (2002) E-Business Initiatives in Food Supply Chains: Definition and Typology of Electronic Business Models. International Journal of Logistics: Research and Applications, 5, 119-138. http://dx.doi.org/10.1080/13675560210148641

[26] Desai, B. and Currie, W. (2005) Towards the ASP E-Business Model: A Conceptual Framework for Mapping ASP Specific Value Propositions. Journal of Internet Commerce, 4, 79-101. http://dx.doi.org/10.1300/J179v04n01_04

[27] Xiang, G.P., Yang, Z., et al. (2014) A Literature Review of Business Models and the Construction of Theoretical Framework from the Perspective of Value Creation: Coding and Refinement Based on Grounded Theory. Foreign Economics \& Management, 36, 32-41.

[28] Zhang, J.W. and Wang, Y.J. (2010) The Research of Conceptual Models of Business Models Base on the Value of the Triangular Logic. Foreign Economics \& Management, 6, 1-8.

[29] Lambert, S. (2008) A Conceptual Framework for Business Model Research. Proceedings of the 21st Bled E-Conference E-Collaboration: Overcoming Boundaries through Multi-Channel Interaction, Bled, Slovenia, 15-18 June 2008, $277-$ 289.

[30] Konstantinos, N.G. and Feng, L. (2011) Developing Sustainable E-Business Models for Intelligent Transportation Systems (ITS). IFIP Advances in Information and Communication Technology, 353, 200-211.

[31] Wu, X.B., Ma, R.F., et al. (2010) How Do Latecomer Firms Capture Value from Disruptive Technologies? A Secondary Business-Model Innovation Perspective. IEEE Transactions on Engineering Management, 57, 51-62. http://dx.doi.org/10.1109/TEM.2009.2033045 
[32] Zilber, N. and de Araújo, B. (2012) Small Companies Innovations in Emerging Countries: E-Business Adoption and Its Business Model. Journal of Technology Management \& Innovation, 7, 102-116. http://dx.doi.org/10.4067/S0718-27242012000200009

[33] Kiani, B., Gholamian, M., Hamzehei, A. and Hosseini, S. (2009) Using Causal Loop Diagram to Achieve a Better Understanding of E-Business Models. International Journal of Electronic Business Management, 7, 159-167.

[34] Huemer, C., Schmidt, A., et al. (2008) A UML Profile for the E3-Value E-Business Model Ontology. 3rd International Workshop on Business/IT Alignment and Interoperability, Springer LNCS, 7-9 June, 1-15.

[35] Glova, J., Sabol, T., et al. (2014) Business Models for the Internet of Things Environment. Procedia Economics and Finance, 15, 1122-1129. http://dx.doi.org/10.1016/S2212-5671(14)00566-8

[36] OuYang, F. (2007) The Structured Analysis of E-Business Models Based on E ${ }^{3}$-Value: Taking DSP as an Example. Scientific Management Research, 25, 73-76.

[37] OuYang, F., Zhao, H.D., et al. (2008) The Simulation Analysis of the Online Publishing Business Model Based on E3Value. China Soft Science, 3, 134-139.

[38] Li, W.W. and Dai, Y. (2011) Value Simulation of Business Model Based on $\mathrm{E}^{3}$-Value Model. Proceedings of the 2011 International Conference on Information, Services and Management Engineering, Beijing, 26-28 December 2011, 484486. 